\title{
Çeltik Tarlalarında Değişik Baklagil Yem Bitkilerinin Kışlık Ara Ürün Olarak Yetiştirme İmkânlarının Araştırııması
}

\author{
* Mahmut DOK ${ }^{1} \quad$ Mevlüt ŞAHIN² $\quad$ Mustafa SÜRMEN³ $\quad$ İsmail SEZER ${ }^{4}$ \\ ${ }^{1}$ Karadeniz Tarımsal Araştırma Enstitüsü, Samsun \\ ${ }^{2}$ Tarla Bitkileri Merkez Araştırma Enstitüsü Müdürlüğü, Ankara \\ ${ }^{3}$ Adnan Menderes Üniversitesi, Ziraat Fakültesi, Tarla Bitkileri Bölümü, Aydın \\ ${ }^{4}$ Ondokuzmayıs Üniversitesi, Ziraat Fakültesi, Tarla Bitkileri Bölümü, Samsun \\ *Sorumlu yazar e-posta (Corresponding author; e-mail): mahmutdok@hotmail.com
}

Öz

Bu çalışma, çeltik tarlalarında değişik baklagil yem bitkilerinin kışlık ara ürün olarak yetiştirilme imkânlarını belirlenmesi amacıyla, 2008-2012 yılları arasında Karadeniz Tarımsal Araştırma Enstitüsünün Gelemen'deki deneme tarlasında yürütülmüştür. Çalışmada Karadeniz çeltik çeşidi ve kışlık ara ürün bitkileri olarak baklagil yem bitkilerinden Tüylü fiğ (Efes-79) (Vicia villosa), adi fiğ (Albayrak) (Vicia sativa), macar fiğ (Tarm beyazı98) (Vicia pannonica) ve yem bezelyesi (P.98) (Pisum sativum subsp. arvense (L.) Asch) kullanılmıştır. Baklagil yem bitkileri, Fahrettinbey arpa çeşidi ile karıştırılarak ekilmiştir. Çalışma sonucunda, çeltik tarlalarında kontrollu sulama yapılan alanlarda, öncelikle macar fiğ ve diğer fiğlerin kışlık ara ürün olarak rahatlıkla yetiştirilebileceği görülmüştür.

Anahtar Kelimeler: Çeltik, baklagil yem bitkisi, ara ürün

\section{Investigation of Growing Opportunities of Different Forage Legumes in Paddy Fields as Winter Catch Crops}

\begin{abstract}
This experiment was carried out in order to determine growing opportunities of different forage legumes in paddy field as winter catch crops in Gelemen experimental field of Black Sea Agricultural Institute between 2008-2012. Karadeniz (Oryza sativa L.) as rice cultivar and Efes-79 (Vicia villosa L.), Albayrak (Vicia sativa L.), Tarm beyazı-98 (Vicia pannonica Crantz.), P:98 (Pisum sativum subsp. arvense (L.) Asch) as winter forage legume catch crops were used in this study. Forage legumes were planted with Fahrettinbey barley cultivar. As a consequence of this study; in controlled irrigated areas in paddy fields, Hungarian vetch (Vicia pannonica Crantz.) and other vetches were seen growing easily, primarily.
\end{abstract}

Keywords: Rice, forage legumes, catch crops

\section{Giriş}

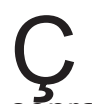
eltik, yeryüzünde buğdaydan sonra en geniş ekim alanı, buğday ve mısırdan sơnra en fazla üretimi olan kültür bitkisidir. Ülkemizde 2011 yılında çeltik ekim alanı 994.000 da. üretim 900.000 ton ortalama verim de 905 kg/da olmuştur (Anonim, 2013a). Türkiye'nin bugünkü pirinç üretimi, iç tüketimi karşılamamaktadır. Türkiye'deki çeltik ekim alanlarının ve üretiminin \%67'si Marmara Bölgesinden, \%25'i de Karadeniz Bölgesi'nden karşılanmaktadır. Kişi başına pirinç tüketimi 2000 yılında 7.17 kg/yıl iken, 2009 yılında 9.68 kg/yıl'a ulaşmıştır. Gerek verim yönünden gerekse kullanılan teknoloji yönünden çeltik üreticileri yurt dışı üreticilerle rekabet edecek güçtedir. Çeltik, rakip ürünlere göre birim alanda karlılık yönünden avantajlı durumdadır (Sezer ve ark. 2012).

Ülkemizde, baklagillerden yonca, korunga, adi fiğ ve buğdaygillerden de burçak gibi birkaç geleneksel yem bitkisinin tarımı yapılmaktadır. Hayvancılığımız ise, geniş ölçüde doğal çayır ve meralara, anızlara ve tahıl samanına dayanmaktadır. Çok değişik iklim ve toprak özelliklerine sahip olan ülkemizde, yem bitkileri gerek kıyı bölgelerimizde, gerekse Orta ve Geçit bölgelerimizde ana ürün ve ikinci ürün olarak üretimde yer alma imkânına sahiptir. Baklagil yem bitkileri, organik tarım sisteminde yeşil gübreleme yolu ile ana bitkinin ihtiyacı olan 
azot ihtiyacının hemen hemen tamamını veya önemli bir bölümünü karşılayabilmektedir.

Karadeniz Bölgesi'nde çeltik alanlarında genelde ekim nöbeti uygulanmamaktadır. En az 5 yıl ve daha fazla üst üste çeltik tarımı yapılmaktadır. Yılda birden fazla ürün alma imkânı bulunan yerlerde birçok tek yıllık yem bitkileri ara ürün olarak yetiştirilmektedir. Ara ürün yetiştirme ise bölge şartlarına göre farklı biçimlerde uygulanmaktadır. Kışları ılık geçen Karadeniz Bölgesi gibi yerlerde ana ürün çeltik hasadından sonra bir yem bitkisi ekilerek yazlık ana ürünün ekiminden önce yeşil ot veya silaj amacıyla kışlık ara ürün olarak değerlendirilebilir (Kün 1985; Sezer ve Mut 2004).

Yağışın yeterli olduğu sahil bölgelerinde veya sulanabilen yerlerde kışlık ve yazlık olmak üzere iki grup ürün yetiştirilmektedir. Kışlık olarak, buğday, arpa, yulaf gibi tahıl türleri, yazlık olarak mısır, ayçiçeği, tütün, soya, pamuk gibi bitkiler sayılabilir. Bu ürün deseni içerisinde, yazlık olarak kışlık ana ürünlerin hasadından sonra silajlık mısır veya hasıl sorgum ikinci ürün olarak yetiştirilebilir. Bunun yanında yazlık ürünlerden sonra tek yıllık baklagil yem bitkileri Ekim-Kasım aylarında kışlık olarak ekilebilir ve bunların ot hasadı Nisan veya Mayıs aylarında yapılabilir. Kış mevsimi bitki gelişimine uygun koşulları taşıdığı için kış döneminde sulu tarım yapılan yerlerde birinci ürün hasadından sonra yazlık ekilecek ürünün ekimine kadar araziler boş kalmaktadır. Sulanan alanların artışıyla ekim nöbeti sistemleri içerisinde sistemi etkilemeyecek şekilde kışlık ara ürün olarak fiğ türleri, İskenderiye üçgülü, yem bezelyesi, mürdümük ve çemen gibi tek yıllık baklagiller saf veya tahıllarla karışım halinde yetiştirilebilir (Anonim 2012).

Kızılırmak Deltası'nda, çeltik tarımı yapılan tarlaların yaklaşık 3/4'ünün denizden yüksekliği 2 m'nin altında olduğundan fazla suların drene edilememektedir. Bundan dolayı mevcut çeltik tarımında uygun toprak, tava ve tohum yatağı hazırlığı zamanında yapılamamakta, çeltik ekim için en uygun tarih Mayıs ayının ilk yarısı olduğu halde ekimler Mayıs sonu ve Haziran ayının ortalarına kadar gecikmektedir. Bölgede fideleme çeltik üretim tekniği ile çeltik yetiştirme dönemi tam olarak değerlendirilerek, düzenli bitki örtüsünün sağlanabilir ve kışlık ara ürün yetiştiriciliği imkânı ortaya çıkabilir (Sirat ve ark. 2012). Ayrıca kışlık ara ürün olarak baklagil yem bitkileri yetiştirildiği takdirde, kendisinden sonra gelecek mısırın ekim zamanında gecikme olmaz, baklagil yem bitkileri ekiminden sonra mısırda verim artışının az olmasına karşılık uzun yıllarda bu artışın daha belirgin olarak ortaya çıkar (Uzun ve ark. 2005).

Ön bitki olarak alınan baklagiller tüm tahıl ürünlerinin ham protein varlığını yükseltmektedir. Baklagillerde görülen bu etki onlardan arda kalan azotla ilgilidir. Ayrıca ön bitki olarak alınan baklagiller tüm tahıl ürünlerinin ve diğer familya ürünleri için çok iyi bir ön bitki olduğu görülmektedir. Bitkisel üretimle ilgi yapılan uygulamaların en yüksek oranda verime çevrilebilmesi ve arzulanan tarımsal başarıya ulaşılabilmesinde doğal ve ekonomik şartlara uygun bir ekim nöbeti planının hayata geçirilmesi ve bu ekim nöbeti programına da bir baklagil cinsinin ilave edilmesi gerekmektedir (Kara ve ark. 2011).

Hayvanların yeterli ve kaliteli yemlerle beslenebilmesi için üretimin yaklaşık 25 milyon ton milyon ton arttırılması gerekmektedir. Yem bitkileri üretiminin artırılması için kışlık olarak yetiştirilen tahılların ardından ana ya da ikinci ürün olarak silajılı mısır, sorgum veya sorgumsudanotu melezi yetiştirilmesi; pamuk, ayçiçeği, çeltik ve şeker pancarı gibi yazlık ürünlerin hasadından sonra kış döneminde uygun fiğ türlerinin yalın ya da karışım olarak ekim nöbetine dahil edilmesi, gerekmektedir (Anonim 2013b).

\section{Materyal ve Yöntem}

Bu çalışmada materyal olarak Karadeniz çeltik çeşidi ve kışlık ara ürün bitkileri olarak baklagil yem bitkilerinden Tüylü fiğ (Efes-79) (Vicia villosa), adi fiğ (Albayrak) (Vicia sativa), macar fiğ (Tarm beyazı-98) (Vicia pannonica) ve yem bezelyesi (P.98) (Pisum sativum subsp. arvense (L.) Asch) kullanılmıştır. Fahrettinbey arpa çeşidi ile karıştırılarak ekilen baklagiller, $\% 70$ baklagil+ \%30 buğdaygil olmak üzere kurulmuştur.

Çalışma, Karadeniz Tarımsal Araştırma Enstitüsü arazisinde çakılı olarak 5 yıl yürütülecek şekilde planlanmıştır. Kışlık ara ürün yem bitkileri tesadüf blokları deneme desenine göre 3 tekerrürlü olarak (4x5) 20 m² $^{2}$ 'lik parsellerde yürütülmüştür. Araziye kışlık ara ürün yem bitkilerinin ekimi çeltik hasadından hemen sonra toprak tavında iken, yağışlardan önce rotovatörle işlenerek serpme olarak yapılmıştır. Dekara atılacak tohum miktarı yörede yapılan araştırma sonuçları ve önerilere 
göre belirlenmiştir. Buna göre yem bitkilerinden $\% 70$ oranındaki baklagiller; tüylü fiğ 10 kg/da, adi fiğ $10 \mathrm{~kg} / \mathrm{da}$, macar fiğ $10 \mathrm{~kg} / \mathrm{da}$ (Vicia pannonica) ve yem bezelyesi $20 \mathrm{~kg} / \mathrm{da}$ (Pisum sativum subsp. arvense (L.) Asch) ile \%30 oranındaki buğdaygillerden arpa $10 \mathrm{~kg} / \mathrm{da}$ tohum kullanılarak atılmıştır. Yeşil ot amacıyla biçimler mayıs ayının ilk haftası yapılmıştır. Yem bitkilerinin hasadından hemen sonra tarla çeltik için hazırlanarak asıl ürün olan çeltiğin ekiminin geciktirilmemesine özen gösterilmiştir.

\section{Bulgular ve Tartışma}

Baklagillerin toprakta besin maddesi ve toprak yapısı üzerine etkisinin belirlenmesi amacı ile deneme 5 yıl olarak planlanmıştır. Ancak yaşanan bazı olumsuz iklim şartları nedeniyle, bazı yıllarda denemeden sonuç alınamamış, bunun üzerine topraktaki değişim safhası gözlenememiştir. Yem bitkileri denemelerinde üç yıl yaş ve kuru ot verimleri alınarak incelenmiş ve varyans analizine tabi tutulmuşlardır.

Çizelge 1'in incelenmesi sonucu görüleceği gibi, yem bitkilerinin verimleri tatmin edici değerlerde bulunmuştur. Üç yıllık sonuçların birleştirilmesi sonucu elde edilen çizelge incelendiğinde, yaş ot veriminin en yüksek Macar fiğinden elde edildiği görülmektedir. Kuru ot verimi ise en yüksek $596 \mathrm{~kg} / \mathrm{da}$ ile yem bezelyesinden elde edilmiştir. Yem bezelyesinin hasatta kuru madde oranının yüksek olması da bunda etkili olduğu söylenebilir. Diğer yem bitkilerinin kuru ot verimleri de göz ardı edilecek kadar düşük değildir. Özellikle kışlık ara ürün olarak düşünüldüğünde bu rakamların hiç de küçümsenmeyecek rakamlar olduğu söylenebilir. Hayvancılık yapan işletmelerin en büyük girdilerinin yem masrafları olduğu aşikârdır. Kaldı ki bu ürün, ana üretimi etkilemeden elde edilmektedir. Onun için elde edilen bu verilerin hem çeltik yetiştirip hem de hayvancılık yapan işletmeler için iyi değerlendirilmesi gerekmektedir. Ancak bu verimi elde etmek için çeltik tarlalarının su tutmaması, kışın biriken suların rahatlıkla tahliye edilebilmesi ve yem bitkileri ekiminin çeltik hasadından hemen sonra yapılması gerekmektedir.

Yem bitkilerinin yerine hasattan hemen sonra tarla pullukla sürülüp su verilerek rotovatörle tarla çeltik ekimi için hazırlanmıştır. Ana ürün çeltiğin ekimleri geciktirilmeden normal ekim zamanında yapılmıştır. Deneme alanına ekimle birlikte gübre verilmemiş, üst gübre olarak ta sapa kalkma döneminde azotlu gübre A.Sülfat formunda uygulanmıştır.

Normal olarak gelişimini tamamlayan çeltik, Hege biçerdöverle hasat edilmiştir. Çeltikte tane verimi, $\mathrm{m}^{2}$ 'de salkım sayısı, salkımda tane sayısı, salkım başına verim, bin tane ağırlığı, bitki boyu, hasat indeksi, kırıksız pirinç randımanı ve yatma değerleri alınarak veriler değerlendirilmiştir. Denemede alınan karakterlere ait iki yılın birleştirilmiş verileri çizelge 2 ve 3'de verilmiştir. Çizelgelerde de görüldüğü gibi incelenen karakterler yönünden iki yılın birleştirilmesi ile yapılan analiz sonucunda yem bitkilerinden sonra ekilen çeltikte ön yem bitkisinin verim ve diğer karakterler üzerine etkisi önemli olmamıştır. Denemenin birleştirilmiş analizi sonucuna göre bitki boyu 110 ile $116 \mathrm{~cm}$ arasında, $\mathrm{m}^{2}$ de salkım sayısı 466 ile 495 adet arasında, salkımda tane sayısı 85 ile 89 adet arasında, hasat nemi \%14.5 ile 14.9 arasında, bin tane ağırlığı 33.1 ile $33.4 \mathrm{gr}$ arasında, hasat indeksi 37 ile 39 arasında, randıman \%60.1 ile \%61.2 arasında verim de 624 ile $697 \mathrm{~kg} / \mathrm{da}$ arasında gerçekleştiği görülmüştür.

Çeltik hasadından sonra tarlada fazla miktarda çeltik anızları kalmaktadır. Bölgemiz çeltik ekim alanlarında özellikle taban arazilerde sonbaharda çeltik hasadından sonra yapılacak olan ekim işlemlerinde bir takım problemler de görülmektedir. Sonbahar yağışlarının başlamasıyla çeltik tavalarına sular dolmakta,

Çizelge 1. Çeltik yerine ekilen yem bitkilerinin birleştirilmiş verim ve kuru madde değerleri

Table 1. Combined yields and dry matters of forage legumes used as a replacament for rice

\begin{tabular}{lccc}
\hline Konular & $\begin{array}{c}\text { Yaş ot verimi } \\
(\mathrm{kg} / \mathrm{da})\end{array}$ & $\begin{array}{c}\text { Kuru ot verimi } \\
(\mathrm{kg} / \mathrm{da})\end{array}$ & $\begin{array}{c}\text { Hasatta kuru madde } \\
(\%)\end{array}$ \\
\hline Macar fiğ (Tarm beyazı-98) & $3020 \mathrm{a}$ & $580 \mathrm{ab}$ & 20.9 \\
Tüylü fiğ (Efes-79) & $2956 \mathrm{ab}$ & $531 \mathrm{ab}$ & 19.7 \\
Adi fiğ (Karaelçi) & $2423 \mathrm{c}$ & $522 \mathrm{~b}$ & 22.7 \\
Yem bezelyesi (P.98) & $2586 \mathrm{bc}$ & $596 \mathrm{a}$ & 23.6 \\
\hline Önem derecesi & $* *$ & $* *$ & \\
DK. $(\%)$ & 5.95 & 6.74 & \\
\hline
\end{tabular}


Çizelge 2. Çeltik yerine kışlık ara ürün yem bitkileri denemesinde çeltikten elde edilen verilerin birleştirilmiş sonuçları

Table 2. Combined results of rice from winter catch crop trials for forage legumes

\begin{tabular}{lccccc}
\hline Konular & Bitki Boyu $(\mathrm{cm})$ & $\mathrm{m}^{2}$ de Salkım (adet) & Salkımda Tane (adet) & Nem $(\%)$ \\
\hline Macar fiğ-Çeltik & 116 & 495 & 88 & 14.9 \\
Tüylü fiğ-Çeltik & 110 & 466 & 89 & 14.9 \\
Adi fiğ-Çeltik & 112 & 485 & 85 & 14.5 \\
Yem bezelyesi-Çeltik & 115 & 475 & 87 & 14.8 \\
\hline Önem derecesi & Öd & Öd & Öd & Öd \\
DK. $(\%)$ & 4.50 & 7.66 & 4.79 & 7.98 \\
\hline
\end{tabular}

Çizelge 3. Çeltik yerine Kışlık ara ürün yem bitkileri denemesinde çeltikten elde edilen verilerin birleştirilmiş sonuçları

Table 3. Combined results of rice from winter catch crop trials for forage legumes

\begin{tabular}{lccccc}
\hline Konular & $\begin{array}{c}\text { Salkım Başına } \\
\text { Verim }(\mathrm{g})\end{array}$ & $\begin{array}{c}\text { Bin Tane } \\
\text { Ağırlı̆ı }(\mathrm{g})\end{array}$ & $\begin{array}{c}\text { Hasat İndeksi } \\
(\%)\end{array}$ & $\begin{array}{c}\text { Randıman } \\
(\%)\end{array}$ & Verim (kg/da) \\
\hline Macar fiğ-Çeltik & 3.0 & 33.4 & 38.7 & 60.1 & 697 \\
Tüylü fiğ-Çeltik & 3.2 & 33.4 & 37.0 & 61.2 & 624 \\
Adi fiğ-Çeltik & 3.0 & 33.1 & 38.1 & 60.6 & 661 \\
Yem bezelyesi-Çeltik & 3.1 & 33.2 & 39.0 & 60.4 & 671 \\
\hline Önem derecesi & Öd & Öd & Öd & Öd & Öd \\
DK. (\%) & 4.04 & 3.12 & 4.85 & 2.73 & 11.44 \\
\hline
\end{tabular}

bu sular da kolay kolay tarladan çekilmemektedir. Dolayısıyla böyle yerlere traktörle işlem yapmak ta hayli zor olmaktadır.

Yem bitkisi, hayvan yemi olarak yetiştirilen, ancak bunun yanında toprak ve suyu muhafaza etme, ekim nöbeti içerisinde kendinden sonra gelen ürünlerin verimini artırma özellikleri taşıyan, doğrudan doğruya veya sonradan yedirilmek üzere hasat edilerek kurutulan veya silajı yapılan bitkilerdir. Buğdaygil ve baklagil yem bitkileri ekildikleri toprakları yalnız verimli hale getirmekle kalmazlar. Aynı zamanda bol miktarda bırakmış oldukları kök ve toprak üstü artıkları ile toprağın organik madde miktarını artırarak yapısını düzeltirler.

Toprağın organik madde yönünden zenginleşmesi ise, özellikle yağışı az olan yerlerde çok önemli husus olan toprağın su tutma ve besin maddeleri kapasitesini artırır.

Hayvancılık açısından kaba yem açığının kapatılması yakın planda mümkün görülmemektedir. Ancak tarım sistemlerinde yapılacak bir takım değişikliklerle önemli ölçüde yem bitkisi üretiminde artış sağlanabilir. Bunlardan bir tanesi de çeltik tarlalarının kışlık ara ürün olarak yem bitkisi üretimine tahsisiyle mümkün olabilir. Çeltik yetiştirilen bölgelerde bunun uygunluğunun yapılacak çalışmalarla üreticiye gösterilmesi gerekmektedir. Yapılan bu çalışmada bazı çeltik tarlalarının uygun şartları taşıdığı takdirde kışlık ara ürün baklagil yem bitkilerinin yetiştiriciliğine uygun olduğu tarlasında kışlık yem bitkisi üretimini beklemek boşunadır. İkinci olarak belki de en önemlisi, çeltik alanının taban arazi olmaması, ya da kışın su tutmaması gerekmektedir. Özellikle deniz seviyesinde olan taban çeltik alanları, bu sisteme uygun yerler değildir. Bazı yıllar, kışları fazla yağış olmayıp verim alma şansı olsa bile, riski yüksek olduğu için bu tip yerler tavsiyemiz dışındadır. Özellikle Çorum, Çankırı, Sinop ve Tosya gibi kışın suların kesilip istenildiği zaman sulama yapılabilecek yerler ve tarladan biriken suların tahliyesinin rahatlıkla yapılabileceği diğer illerin çeltik alanlarında da bu model yetiştiricilik yapılabilir.

Kaba yem açığının kapatılması ile ilgili tüm önerilerde yem bitkilerinin münavebeye alınması veya kışlık ara ürün olarak pamuk, mısır vs. gibi yazlık ürünlerle önerilmesi dikkati çekmektedir. Hâlbuki çeltik tarlalarının da dikkate alınması gerekmektedir. Ülkemizde yaklaşık 990.000 da çeltik ekimi yapılmaktadır. $\mathrm{Bu}$ alanın \%5 inde bu sistemi yaptığımız takdirde, ortalama dekardan $500 \mathrm{~kg}$ kuru ot alınması mümkün görülmektedir. Bu da yaklaşık olarak 25.000 ton kuru ota tekabül ekmektedir. Hem de kaliteli bir ot olacağı da düşünüldüğünde, hiç de küçümsenmeyecek bir miktar olarak karşımıza çıkar. Sadece kaba yem olarak düşünüldüğünde önemli bir yem kaynağı olan çeltik tarlalarının baklagil yem bitkisi olması nedeniyle toprak üzerine olan olumlu etkileri de ayrı bir kazanç olmaktadır. 
Dok et al. "Investigation of Growing Opportunities of Different Forage Legumes in Paddy Fields as Winter Catch Crops"

\section{Sonuç}

Çalışma sonucunda, çeltik tarlalarında kontrollu sulama yapılan alanlarda, öncelikle macar fiğ ve diğer fiğlerin kışlık ara ürün olarak rahatlıkla yetiştirilebileceği görülmüştür.

\section{Kaynaklar}

Anonim, 2013a. http://www.tuik.gov.tr/VeriBilgi.do?alt id $=45$

Anonim, 2013b. http://www.zmo.org.tr/resimler/ekler/ 7e77c835af3d2a8_ek.pdf

Anonim, 2012. http://www.tusedad.org/upload/files/Y em\%20Bitkileri\%20\%DCretimi\%20ve\%20 Sorunlar\% FD.pdf. (Erişim tarihi:28.12.2012)

Kara B., Kara N., Akman Z. ve Balabanlı C., 2011. Tarla bitkilerinde ekim nöbetinde ön bitki değeri ve etkileri. Batı Akdeniz Tarımsal Araştırma Enstitüsü Derim Dergisi, 28(1): 12-24
Kün E., 1985. Sıcak İklim Tahılları. Ankara Üniv. Ziraat Fak. Yay. 875, Ders Kitabı: 240, Ank.Üniv. Basımevi, Ankara

Sezer İ., Akay H., Öner F. ve Şahin M., 2012. Çeltik üretim sistemleri. Türk Bilimsel Derlemeler Dergisi, 5(2): 06-11

Sirat A., Sezer İ. ve Akay H., 2012. Kızılırmak deltası'nda organik çeltik tarımı. GÜFBED IGUSTIJ, 2(2): 76-92

Uzun A., Karasu A., Turgut İ., Çakmak F. ve Turan Z.M. 2005. Bursa koşullarında ekim nöbeti sistemlerinin mısırın verim ve verim öğeleri üzerine etkisi. Uludağ Üni. Ziraat Fak. Dergisi, 19(2): 61-68

Yavuz T., Töngel Ö. and Albayrak S., 2006. Performances of some annual forage legumes in the Black Sea coastal region. Asian Journal of Plant Sciences 1: CCCC, ISSN 1682-3974 